\title{
Pedagogic change by Zambian primary school teachers participating in the OER4Schools professional development programme for one year
}

\author{
S. Hennessy, B. Haßler, R. Hofmann \\ Faculty of Education \\ University of Cambridge \\ 184 Hills Road \\ Cambridge CB2 8PQ \\ UK \\ Tel: $+44(0) 1223767657$
}

\begin{abstract}
Supporting and upskilling teachers are essential to enhancing the quality of learning in developing contexts - the focus of Education For All - yet little evidence exists concerning what kinds of teacher education are actually most effective and what changes in "quality" are desired and feasible. This paper illustrates how a concrete, research-informed school-based, model of professional development in sub-Saharan Africa can address the quality agenda. It reports on a trial of a pioneering, multimedia programme supporting interactive mathematics and science teaching using open educational resources and classroom digital technology, where available. The programme was carefully adapted to the Zambian context and ran weekly for one school year with 12 teachers in a low-resourced, primary school. The study examined the impact on teachers' thinking and classroom practices. Data were derived from observations, lesson and workshop recordings, teacher interviews, portfolios and audio diaries. Through a teacher-led workshop approach and trialling new pedagogical strategies, teachers raised their expectations of pupils, adapted to learners' knowledge levels, used more practical and group work, and integrated technology use. Pupils built deeper understanding of subject matter, were actively engaged, worked collaboratively and used digital technologies for problem solving.
\end{abstract}

\section{Keywords}

Teacher professional development; digital technology; sub-Saharan Africa; interactive pedagogy; Zambia; Open Educational Resources

CITATION: Hennessy, S., Haßler, B., \& Hofmann, R. (2015). Pedagogic change by Zambian primary school teachers participating in the OERS4Schools professional development programme for one year. Research Papers in Education. http://dx.doi.org/10.1080/02671522.2015.1073343

Hennessy et al. (2015). Pedagogic change ... - 1 


\section{Introduction and design principles for OER4Schools}

The key imperative for the post-2015 development agenda is shifting from increasing access to improving quality of teaching and learning in universal primary education (UNESCO, 2014; Schweisfurth, 2015). However, we need to better understand the processes and possibilities of supporting teacher learning in developing contexts specifically. Existing research literature offers insights into why, despite past interventions, many current school systems in sub-Saharan Africa (SSA) are unable to cope with the demand of quality. The excellent summary of previous largescale teacher education research by Moon et al. (2013) indicates the well-known challenges, pointing out that current models often focus on pre-service college education, where curricula are not aligned or relevant to school curricula, nor do they typically integrate teaching practice with a focus on learning. The literature points to forms of continuing professional development (CPD) that are considered productive, cost-effective and scalable - notably school-based models with a focus on practical teaching and learning (Moon, 2007; Schwille and Dembélé, 2007). However there is as yet little concrete evidence of what kind of CPD works best, nor of what aspects of the 'quality' concept are most significant (Glewwe and Kremer, 2006). Our work addresses these gaps through defining and conceptualising 'quality' primarily through an increased focus on student learning and illustrating how such pedagogic change can take shape in practice in this setting. The EdQual work indicates, moreover, that to impact positively on outcomes for disadvantaged learners, African teacher education needs to incorporate 'structured pedagogy' (Tikly 2011). Our OER4Schools programme directly addresses this need and our research tests its success. We begin by outlining the theoretical underpinnings of the design of our programme, drawing on studies in other contexts.

\subsection{Conceptualising teacher professional learning: Linking critical reflection with classroom implementation}

Our conceptual starting point is an understanding of teacher learning as being situated and social: it requires opportunities to engage in authentic activities and participate in rigorous and critical debate within discourse communities (Wallace, 2003). However, we argue that while shared reflection on practice is intuitively appealing and generally the accepted mechanism underlying effective CPD, there is little evidence that alone it results in improvement of teaching practices. Rather, research has illustrated that translating critical analysis into conscious and purposeful action to raise performance is vital (Antoniou and Kyriakides, 2011; Cornford, 2002). Thus, teachers need to be aware of theoretical knowledge relating to learner achievement, as well as to plan and carry out teaching in a way that makes use of this knowledge (Antoniou and Kyriakides, 2011). We would assert that teacher reflection comes into the process in relation not only to the outcomes of classroom trialling but first, to critique new theoretical ideas encountered and reflection with peers 
upon the implications for developing practice in their own contexts. This complex cycle underpins OER4Schools, a unique Open Educational Resource (OER) in the form of a professional learning programme for teachers in schools. It illustrates a concrete research-informed way of addressing these objectives of

(1) making accessible and supporting ownership of theoretical knowledge about learning and providing opportunities for critical reflection and debate;

(2) offering structured opportunities for planning lessons that make use of those theoretical understandings; and

(3) providing a context within which to implement, and then (individually and collectively) reflect upon, and modify, those plans.

It achieves these via its carefully selected choice of pedagogical strategies - each of which has a weight of underpinning research evidence that the resources explicitly reference for participants and its integration of teacher-devised classroom activities. These are associated with each generic strategy, yet focused upon impending lesson topics and aims. Importantly, new strategies are trialled in workshops and then classrooms, and learning is shaped by the contexts of trialling. Hence the programme strives to meet the challenge of offering an evidence-based and theory-driven approach to educational improvement (ibid., p. 309).

The OER4Schools approach is thereby closely aligned with contemporary models of CPD, and "professional learning communities" that encourage peer learning, observation and feedback, offer scope for teachers to identify their own CPD focus, include concrete, experiential tasks and focus on immediate teaching needs and everyday, first-hand classroom experiences (Cordingley et al., 2004; OECD, 1998; Twining et al., 2013; Wells, 2007). A systematic review of research on professional development by Cordingley et al. (2003) found that such models include processes to encourage, extend and structure professional dialogue, and they sustain CPD over time so as to enable teachers to embed practice in their classrooms. We know that teacher learning proceeds gradually and hesitantly as horizons of understanding expand, rather than through sudden leaps of insight (Wallace, 2003).

In OER4Schools, for both teachers and pupils, the emphasis is on participation in inquiry through experimenting with classroom strategies, including problem posing and problem solving (ibid.). In particular, the use of digital technology is considered a key way of supporting inquiry-based learning, although our programme incorporates materials for contexts both with and without access to technology. Using new technologies is motivating to teachers and learners alike, and can act as a springboard for classroom innovation. However, the research literature established long ago that technology alone has no "impact"; it is now assumed that teacher support for developing and extending practice and learner-centred pedagogy is crucial (e.g. Twining et al., 2013). Moreover, many believe that CPD for technology use, again, "needs to include a focus on underpinning principles and theories of education relating to the philosophy of education, learning theory and change management" (ibid., p.432). Thus teachers can make informed decisions about educational practices and can apply theory to evolve their practice in response to changing conditions (ibid., 


\subsection{Stimulating critical professional reflection and inquiry through the use of multimedia resources}

In turning the sequence of professional learning outlined above into a mediating structure to support its realisation in practice, our research draws on earlier findings on stimulating the process of critical inquiry in practice. A key design principle is that an external stimulus (in our case, the OER4Schools multimedia resources and their underpinning in educational research) and a safe climate for both trialling new ideas and challenging one's peers are important. It is well established that CPD benefits from external expertise linked to school-based activities (Cordingley et al., 2003). This can help to avoid groups becoming overly inward looking, to expose them to new ideas, and to challenge local norms of practice and even shared values (Rainio \& Hofmann, 2015). Recognising potential discordance in values may hereby act as a driver for change (Watson, 2014). Teachers themselves emphasise the value of seeing new approaches in practice (either through videos or modeling), trying them out and reflecting critically on their success with other teachers (Butler et al., 2004). Analysis of concrete classroom episodes helps teachers develop a better grasp of children's learning processes (Scherer and Steinbring, 2006) and understandings (Sherin, 2007). It is also important for teachers to scrutinise their own practices and challenge their own underlying assumptions along with those of curriculum or professional learning materials (Cochran-Smith and Lytle, 1999).

In our programme, the role of video was a central external stimulus for reflection and inquiry. Footage of unknown teachers allows viewers to experience and more freely critique a wider range of practices, raising the possibility of comparing and contrasting alternate pedagogical strategies (Sherin, 2007). Teachers can thereby reflect on, and see, their own practice more clearly (Hiebert, cited in Ulewicz et al., 2001, p. 10). Using video non-prescriptively and using multiple instantiations of theory can help teachers to abstract and understand the underlying pedagogical principles (Randi and Corno, 2007, p.336-7); their interpretations may inform pedagogical decisions. However, making alternative values and pedagogical principles explicit is necessary to avoid interpretation within the confines of teachers' and schools' current frameworks of reference and cultural values (Rainio \& Hofmann, 2015).

Central to the use of external multimedia stimuli is the idea of "guided noticing" (van Es and Sherin, 2008) as the group collectively watches a clip, with the intention of promoting critical reflection. 'Noticing' involves

(a) identifying what is important in a specific teaching situation;

(b) using what one knows about the context to reason about a situation;

(c) making connections between specific events and broader principles of teaching and learning.

For example, the OER4Schools unit on "questioning" contains these prompts: 
- What did you notice about the teacher's questions in this clip?

- How did the teacher handle multiple responses?

- How would you improve the teacher's questions?

- Plan your own activity with open-ended questions.

Reflection upon both teachers' own and others' practices is thereby structured. O'Sullivan's research with underqualified teachers in Namibia showed that teacher reactions to unstructured lesson observations and videos were passive, whereas reflective questions and prompts were successful in increasing teachers' reflective analysis (O'Sullivan, 2002). Marsh and Mitchell (2014) argue that video not only captures the reality and complexity of classrooms but develops capacity for reflection, analysis and noticing through dialogue with peers that makes multiple perspectives and lenses available. Ideally noticing is supported by the programme facilitator, where such a person is available. While the role of the facilitator has received little attention in the research literature, we do know that it is pivotal in setting up and helping teachers to maintain discussion norms (Coles, 2012); in our own programme, their familiarity with the programme's underlying ideas puts them in a strong position to assist peers, assuming that facilitators have fully understood those ideas. This understanding ideally needs monitoring to avoid superficial understanding and 'dilution'.

In the cases of both a human facilitator and of prompts built into multimedia resources, maintaining the focus on asking questions about participants' own situations, including causes of concern or areas to work on, and creating a culture of respectful and constructive commentary, are both essential to pre-empt evaluative, overly critical, overgeneralised or uninformed and unproductive remarks about the (unknown) teacher viewed (Duffin et al., 1991; NRC, 2001). Any interpretations need to be grounded in what is actually observed (Duffin et al., 1991). The use of video clips with audio- or text-based anecdotes describing, for example, the outcomes of trialling a new approach, and pupils' responses, is useful in stimulating participants' own responses, vicarious involvement and own related anecdotes (ibid.). In the OER4Schools resource, the facilitator or educator notes are "metacommenting" on the featured teacher's experience and actions (Coles, 2012). It is also necessary for the facilitator to build confidence by supporting the group in being able to utter illformed (but refinable) ideas without feeling foolish; in our programme peer facilitators reflect alongside their colleagues.

\subsection{Promoting a focus on learning}

Above, we have set out the elements (from exposure to theory and shared critical reflection to concrete pedagogic planning and trialling) that we argue prior research suggests as a foundation for professional learning, and illustrated the structure and materials of a concrete pedagogic intervention programme that builds on these understandings. In this section we draw out and conceptualise a core aspect that we argue may be the central mediating factor of pedagogic change within such a programme.

In addition to considering what teachers notice when watching the pedagogic multimedia resources, we argue that a critical feature of effective professional development is focusing teachers' attention on what children are doing, understanding and learning in classrooms. This includes developing 
awareness of how learning needs vary between individuals, and of the consequent need for differentiation and scaffolding to support learners to go beyond their current levels of understanding. A review of work on scaffolding by Van de Pol, Volman, and Beishuizen (2010) pointed out that students' contributions and responses inevitably shape the interaction in important ways; OER4Schools helps teachers to tune into this. However, a focus on learning is not normally highlighted in Zambian education, where the norm is a transmission-based model of teaching and superficial rote learning without an emphasis on sense-making or real-world application (e.g. Carroll, 1996; Morrow, 1998; Moyo and Modiba, 2014). In Zambia and other countries with a policy culture that encourages curriculum coverage and teaching to the test (James and McCormick, 2009 , p. 982), teachers commonly believe they can only discover what children have learned through tests (Avalos, 2011). Where "group work" is practised, pupils typically carry out individual tasks while seated in groups (e.g. Ngware et al., 2014), without recognition that they need to develop collaboration skills.

As in many SSA countries, attainment in Zambia (located at 141/187 countries on the HDI) is low: for example, after six years of schooling, $70 \%$ of Zambian children do not achieve basic numeracy (e.g. UNESCO, 2010, p. 106). Only 57\% even complete primary school (compared with $82 \%$ in neighbouring Zimbabwe: Mitra et al., 2011). Primary school enrolment has nevertheless risen owing to implementation of a free basic education policy in 2002, although this has had less impact on underrepresented groups including girls, children from poor families and rural areas (UNICEF, 2015). Attainment levels are constrained by large class sizes, low resource levels both at home and school, poorly qualified teachers, and pupil absenteeism, related to learners' experiences of hardship (including poor nutrition and lack of parental funds for school uniform/materials), bereavement, teenage pregnancy and early marriage (especially prevalent in Zambia) and often lack of parental support for their education. The practice of multiple shifts in heavily enrolled schools reduces teacher pupil contact time (MOEVSTEE, Zambia 2014). Moreover, teachers' family commitments and long journeys to school can curtail time available for professional learning and contribute to teacher absenteeism. Low salaries and delayed payments (leading to moonlighting) also exacerbate the latter.

Such factors influence introduction of new forms of pedagogy (and technology use), which must accommodate to the real situations in which teachers work in a low-resourced context. Constraints related to poverty levels are not of course directly alleviated through such an intervention; however, the extent of their influence may be somewhat mitigated through devising culturally sensitive programmes designed to support teachers and learners in participating in new practices. Teachers frequently reported, for instance, that pupil absenteeism had decreased as a consequence of our programme. Moreover, some additional, key contextual factors arose which our programme was designed - and found - to influence positively. These included: teachers' views of pupils and their capabilities, views of their own capabilities, perceptions of the gap/connection between school and pupils' families/communities, pupils' English language competence, and influence of national policies and requirements (including curricula and school inspections). We elaborate upon these constraints further, as well as supporting factors, in a forthcoming article (Haßler, Hennessy \& Hofmann in press), characterising those emerging in our own studies at the three levels of teacher, school, and the wider community and policy context. The central element in the OER4Schools 
programme design linked to mitigation of these factors was the strong emphasis on teachers supporting learning and attending to levels of pupil participation, as we illustrate in the Findings section.

A small number of case studies have charted development of more learner-centered pedagogy in SSA (e.g. Uworwabayeho, 2011; Rubagiza et al., 2011; Buckler and Gafar, 2013; Wolfenden et al., 2010; Power, 2013; Nsibande and Modiba, 2012) but research in this area is fragmented and small scale, and some of it is inconclusive or lacks rigour. Data from mathematics lessons filmed by Ngware et al. (2014) in 72 primary schools in Kenya led to the claim that "students' learning achievement can be improved through quality teaching, even when other conditions such as class size are not conducive" (p.3). The study focused on so-called "recitation lessons"; confusingly, these were defined to include a range of techniques, including teacher-led question-and-answer focusing on factual recall, whole class chorus, oral reading, as well as more learner-centred approaches, such as learners demonstrating problem solving and engaging with other learners. Learner involvement through such teaching methods, and use of stimulating visual teaching aids during mathematics lessons, produced better learning outcomes than passive individual seat work and whole class chorus (although this was also part of a recitation lesson), but only in low performing schools. Other research in mathematics education - in both developing and more developed countries - shows that it takes time for traditionally educated teachers to see the importance of, and incorporate, opportunities for learners to pose and explore problems, and to listen to their solutions (Suurtamm and Vézina, 2010). Shifting the focus from "telling to listening" requires sustained professional development geared towards developing teachers' skills at listening and interacting with pupils' thinking (Carroll et al., 2000).

The strongest evidence for which pedagogical practices are most effective in supporting student learning in low- and middle-income countries, and how to develop them, comes from an in-depth and rigorous review of 54 studies by Westbrook et al. (2013). The three specific strategies found to promote interactive pedagogic practices that are more likely to impact student learning outcomes were:

- feedback, sustained attention and inclusion;

- creating a safe environment in which students are supported in their learning;

- drawing on students' backgrounds and experiences.

These strategies underpinned development of six teaching practices that the most effective teachers prioritise (ibid., p.2):

- flexible use of whole-class, group and pair work where students discuss a shared task;

- frequent and relevant use of learning materials beyond the textbook;

- open and closed questioning, expanding responses, encouraging student questioning;

- demonstration and explanation, drawing on sound pedagogical content knowledge;

- use of local languages and code switching;

- planning and varying lesson sequences.

The authors conclude: "Brought together as a package in an intervention or carefully constructed curriculum, supported by relevant professional development, they might make a considerable 
impact on student learning" (ibid., p.2). Our OER4Schools programme explicitly incorporates these practices and strategies (although formulated independently). One illustration is perhaps worth making, concerning relating our programme to "drawing on students' backgrounds and experiences". Another contextual constraint is the largely theoretical curriculum in Zambia and other SSA countries which means that formal learning is often divorced from everyday life outside schools. OER4Schools programme begins to blur this boundary by inviting explicit links with everyday knowledge both (a) in terms of content of our suggested inquiry-based activities being codevised with teachers to be closely aligned with community activity (e.g. investigating water retention properties of local soil types) and (b) through encouraging children to bring in their own informal understandings to classroom activities. Roth and Lee's (2004) ethnographic work suggests that such linking serves to encourage students' lifelong participation in and learning of sciencerelated issues.

This paper reports on Phase 3 of the programme in which we designed, implemented and evaluated a substantial CPD programme aimed at developing more interactive teaching in a participatory way: with peer facilitation by a Zambian teacher working with remote support from our team. The study examined the impact of involvement in the programme over a whole school year on teachers' thinking and practice. It sought to establish what degree of change is possible within a challenging, low-resourced context.

\section{Development of the OER4Schools programme}

\subsection{Overview of Phases 1 and 2 and emerging guidelines}

Phase 1 (pilot, 2010) assessed the feasibility of supporting interactive forms of subject teaching in conjunction with providing OER to computer- and Internet-equipped primary schools in Zambia (Haßler, Hennessy \& Lubasi, 2011; Hennessy, Haßler \& Mwewa, 2012). It was initiated in response to the need identified by the Zambian NGO iSchool, and their school partners, to create schoolbased professional development opportunities supporting technology integration, adapted to the local context. We worked over a six-month period with teachers in three primary schools in Lusaka province, all serving underprivileged communities.

Phase $2(2010$ - 2011) involved two of the original schools (Haßler, Hennessy \& Cross, with Chileshe \& Machiko, 2014). It benefited from the parallel Appropriate New Technologies to Support Interactive Teaching in Zambian schools project (Haßler, Hennessy, Lord, Cross, Jackson \& Simpson 2011) which provided a small number of mobile devices and non-digital resources. Phase 2 culminated in professional filming of six lessons (two each with three teachers), for use in the OER4Schools professional learning programme, described in Section 2.2.

The programme was partially co-developed and contextualised by Zambian teachers and other local partners. This resonates with the observation by Mubanga (2012), Director General, Zambia Ministry of Education, that knowledge needs to be actively acquired by participants, importance

Hennessy et al. (2015). Pedagogic change ... - 8 
needs to be placed on local values and expertise, and existing capabilities need to be drawn upon. Our overall approach to "quality" is framed by the principles of social justice (Tikly and Barrett, 2011) emphasising participation and voice, focusing on enabling the school environment in Tikly's (2011) context-led model for conceptualising educational quality. As conceptualised through the Zambian "School Program of In-service Training for the Term" (SPRINT) programme which seeks to initiate sustainable CPD, including teacher group meetings, OER4Schools programme responds to the need for cost-effective, large-scale development opportunities for teachers (including pedagogical). The OER4Schools programme partly achieves this through the use of OER, and embodies the OER freedoms (legal, technological/access, participation; Haßler \& Mays, 2014) which are related to the wider discourse of 'open development' (Smith et al., 2011). For instance, the resource is hosted on a wiki, allowing decentralised authoring. Throughout the programme, the facilitator, participants and developers (both in the UK and in Zambia) jointly and continuously reflected on the resource itself, incorporating revisions and suggestions, some of which derived from audio reflections and workshop recordings (see Section 3.3).

Our findings from the first two programme phases confirmed that CPD opportunities are essential for teachers to become familiar with new pedagogies and technologies and to make creative use of them. However, teachers reported that typically, effective CPD is not readily available. Throughout the initial phases we observed slow but continual change in practice. Teachers were ultimately able to teach interactive lessons (incorporating technology), including a degree of improvisation to address challenges (Haßler, Hennessy \& Cross, with Chileshe \& Machiko, 2014).

Informed by the research literature, we arrived at the following guiding principles for in-school professional development to support more interactive pedagogical thinking and practice in this and other, similar contexts:

- Reflective dialogue through post-lesson review and planning, along with video-stimulated discussion, explicitly encourages a cycle of reflective practice and critical inquiry, and supports ongoing, deep change.

- Teachers are construed as professionals, capable of critiquing and developing their practice.

- The programme is practical and practice focused through immediate development of concrete teaching plans.

- Dialogue poses sensitive and structured challenges, focusing on pupils' learning needs, and raising expectations of their capabilities.

- Face-to-face opportunities support learning from, and with, mentors and colleagues.

- Concerns and constraints of teachers and the school environment are taken into account, offering culturally appropriate and sustained development opportunities.

\subsection{Overview of the OER4Schools programme}

The first two phases culminated in a school-based, multimedia professional development programme designed to offer teachers in English-speaking SSA new, sustained opportunities for peer learning, adapting the established principles of effective CPD to a new context (OER4Schools: http://www.oer4schools.org). 
In more detail, the programme supports active, collaborative learning of mathematics and science — generally, and using mobile technologies (tablets, netbooks, etc.) where available. The materials include unique, professionally filmed video exemplars of interactive practices in Zambia, plus some exemplars from South African mathematics classrooms, produced in conjunction with the African Institute for Mathematical Sciences Schools Enrichment Centre (AIMSSEC) ${ }^{1}$. The six units cover interactive teaching principles, group work, questioning, dialogue, Assessment for Learning, inquiry-based learning and communication with other stakeholders. There are 28 sessions in total, roughly constituting a year-long programme of weekly sessions.

The programme follows a reflective cycle (Figure 1). Each session provides a structured two-hour workshop (with scope for adaptation to teachers' own purposes and settings and responding to issues arising). Each workshop consists of stimuli for discussion (such as video clips, background reading, podcasts, diagrams, presentations), consolidating teaching skills (through pedagogical ideas, including ideas for lesson activities), exploration and clarification of pedagogical concepts (e.g. through focused activities in workshops), the development of technical skills (through ICTbased activities, integrated into the workshop), as well as devising activities that extend current practice, focusing on learning, and exploiting the technologies available in each school context. ICT-based activities draw on free and open source software, including using the Ubuntu operating system, collaborative writing (EtherPad), spreadsheets (OpenOffice), mathematical software (GeoGebra), handling images, and mind mapping. Many sessions are supplemented with other OER, including materials from other organisations active in Zambia and elsewhere. Importantly, each session features (concealable) educator notes in shaded boxes interspersed with the main text, providing guidance to the facilitator that do not appear in the participants' version.

In the week(s) following the workshop, teachers try out the planned activities, and complete other follow-up activities (such as mutual lesson observations of colleagues, and individual audio reflections). At the start of the next workshop, lesson reviews entail extended conversations, collectively reflecting on the relative successes and difficulties of teaching the lesson, including technology use.

\footnotetext{
${ }^{1}$ http://aimssec.aims.ac.za/
} 


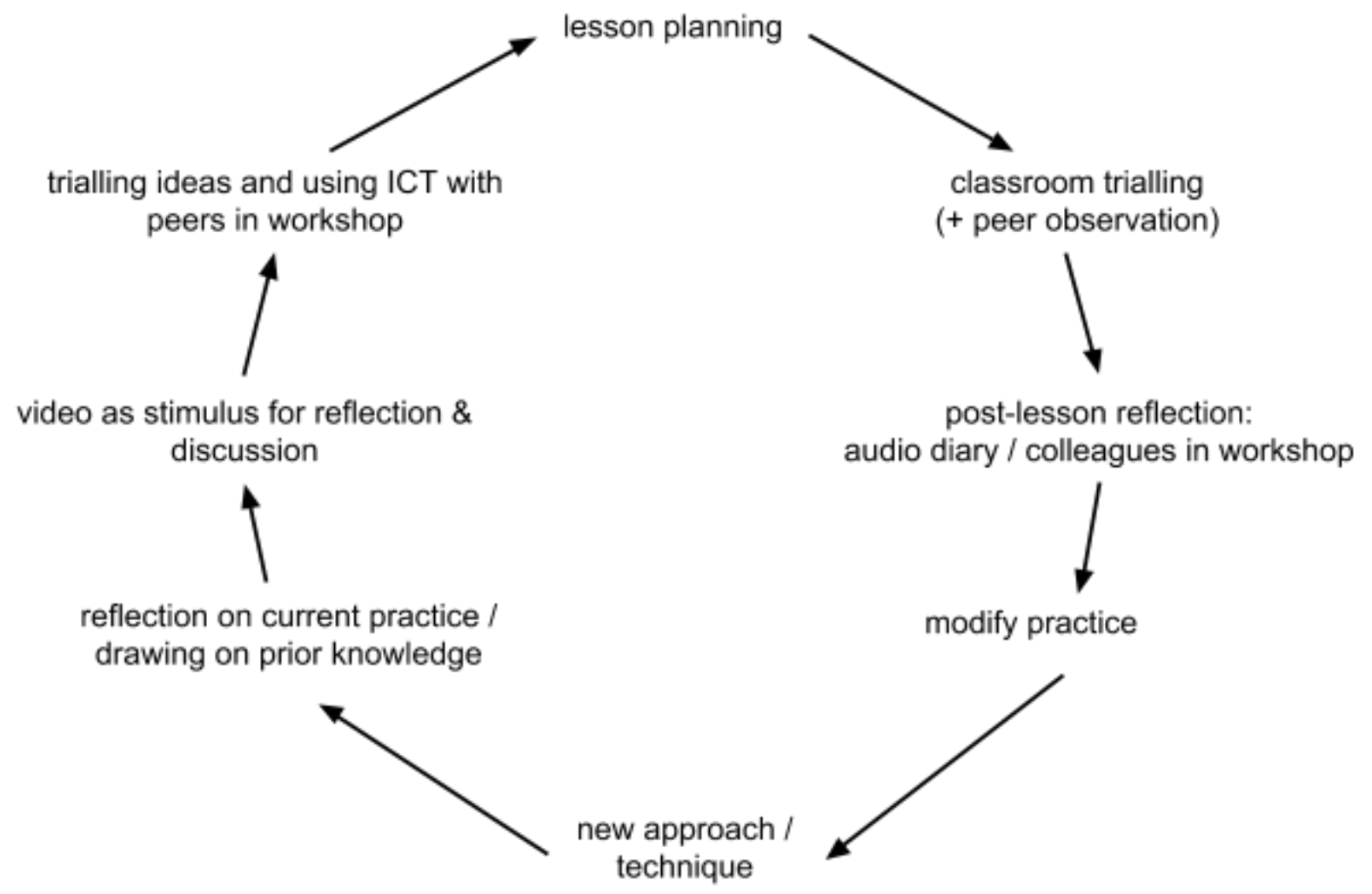

Figure 1. Reflective Cycle

\section{A 1-year trial: methods of data collection and analysis}

In Phase 3 of the OER4Schools programme (reported here), we trialled the programme in Grades 4-6 (predominantly ages 9-12) over the course of the 2012 school year. The OER4Schools resource development continued in parallel with the trial, with lessons learnt from the earlier parts feeding into the development of later parts, leading to a complete draft version by October 2012.

Our research questions were:

- What accounts of pedagogic and professional change are there in the data and to what extent, and in what ways, do these focus on pupils and their learning?

- What do the teachers notice when describing their classroom practices and what evidence is there of the teachers beginning to see their practice and their pupils' learning in new ways? 
- What impacts do the teachers perceive these changes to have had on their pupils?

\subsection{Participants}

Chalimbana Basic School (Chongwe, Zambia; $50 \mathrm{~km}$ from Lusaka) is a mixed-sex government primary school with around 35 teachers and 1,000 pupils. It is poorly resourced and serves a predominantly disadvantaged, semi-rural community; many children are orphaned or otherwise vulnerable. There is a small intake from families where a parent works at one of the local professional institutions, who are comparatively advantaged. The mother tongue of many children in the Chongwe region is Nyanja (also known as Chewa) or Soli, which is related to Tonga (one of the official Zambian languages). A small proportion who have migrated from other regions will have first learned another Zambian language, often Bemba. Twelve teachers (all Grade 4-6 teachers: one male and 11 female) with varying levels of professional experience and qualifications took part. Teachers in the school were multilingual; just under half spoke Nyanja, a third spoke Bemba and a fifth spoke Tonga or Soli. Participation in this study was voluntary for the teachers and pupils, and explicit written permission to record conversations, film lessons and gather evidence for the study was obtained. Teachers had little prior experience with ICT, apart from some personal use of desktop computers.

\subsection{Digital technology and infrastructure}

The school had mains electricity but little functioning technology when the OER4Schools programme was first piloted in 2009. For the third phase described here, 12 pupil netbooks were purchased. Given the typical class size of around 40, pupils had around 2 hours shared access (in groups of 4) per week, and teachers collapsed lessons into a 2-hour block accordingly.

In addition to the equipment for classroom use, we set up a teacher lab with four larger laptops. All netbooks and laptops run Ubuntu, with a range of "open-ended" interactive applications, (as illustrated above). A local Wi-Fi network (using Nanostations) linked netbooks and laptops to each other, and to a central (low-power, high-resilience) server, providing content for lesson use, as well as allowing teachers to upload their own content and audio reflections.

The server also acted as a gateway for the teacher laptops to connect to the satellite internet of the adjacent college, allowing teachers to browse the internet - slowly and intermittently, but nevertheless this was useful for making resources available offline for later classroom use. In terms of the speed, reliability and cost of the internet connection, it was not feasible for the classroom netbooks to connect to the internet directly, and these pre-empted potential parental concerns too.

\subsection{Data gathering}

Data collection took place continuously (audio diaries, workshop audio recordings), as well as during a number of visits to the schools (classroom and workshop observations, semi-structured interviews, and focus groups). Data collection is summarised in Table 1. The initial visit in January 
2012 also served to launch this phase of the programme, and to set up the technology infrastructure.

\begin{tabular}{|c|c|c|}
\hline Method (data type) & Quantity / timing & Focus \\
\hline $\begin{array}{l}\text { Semi-structured teacher \& } \\
\text { SLT interviews, focus } \\
\text { group (audio transcripts) }\end{array}$ & $\begin{array}{l}\text { March 2012: } 7 \text { individual } \\
\text { teachers }+ \text { facilitator }+ \text { deputy } \\
\text { teacher }+ \text { headteacher; focus } \\
\text { group with } 4 \text { teachers }+ \\
\text { facilitator } \\
\text { October-November } 2012: 5 \\
\text { teachers }+3 \text { group interviews } \\
(8 \text { teachers })+\text { facilitator }\end{array}$ & $\begin{array}{l}\text { Participants' experiences and } \\
\text { perceived outcomes of the } \\
\text { programme; opinions about } \\
\text { interactive teaching and change } \\
\text { in their classrooms/schools }\end{array}$ \\
\hline $\begin{array}{l}\text { Workshop audio } \\
\text { recordings; some } \\
\text { workshop video recordings } \\
\text { (Flip-style camera); } \\
\text { feedback from facilitator } \\
\text { (partially transcribed) }\end{array}$ & $\begin{array}{l}\text { February-September 2012: } 17 \\
\text { workshop recordings } \\
\text { March: } 3 \text { workshops observed }\end{array}$ & $\begin{array}{l}\text { Lesson review; lesson planning; } \\
\text { logistics }\end{array}$ \\
\hline $\begin{array}{l}\quad \text { Lesson } \\
\text { observations (semi- } \\
\text { structured observation } \\
\text { notes; lesson plans; } \\
\text { photographs from lessons } \\
\text { and pupil work; some } \\
\text { video recordings of } \\
\text { lessons) }\end{array}$ & $\begin{array}{l}\text { January 2012: } 4 \text { baseline } \\
\text { lesson videos } \\
\text { March 2012:6 teachers, one } \\
\text { lesson each observed and } \\
\text { filmed } \\
\text { October -November 2012: } 5 \\
\text { lessons professionally } \\
\text { filmed,associated materials } \\
\text { collected }\end{array}$ & $\begin{array}{l}\text { Capturing development and } \\
\text { range of pedagogical practices }\end{array}$ \\
\hline Portfolios & $\begin{array}{l}\text { October 2012: } 9 \text { portfolios, } 5 \\
\text { accompanying audio } \\
\text { reflections }\end{array}$ & $\begin{array}{l}\text { Participants' reflections on, and } \\
\text { evidence for, trialling of } \\
\text { selected interactive techniques } \\
\text { and ICT use }\end{array}$ \\
\hline $\begin{array}{l}\text { Post-lesson audio } \\
\text { reflections }\end{array}$ & 37 reflections throughout 2012 & $\begin{array}{l}\text { Participants' reflections on } \\
\text { trialling of interactive }\end{array}$ \\
\hline
\end{tabular}

Hennessy et al. (2015). Pedagogic change ... - 13 


\begin{tabular}{|c|c|c|}
\hline & & $\begin{array}{l}\text { techniques ( } 4-5 / \text { person), and } \\
\text { ICT use }\end{array}$ \\
\hline Teacher surveys & 25 surveys in January 2013 & $\begin{array}{l}\text { Demographic data, and basic } \\
\text { information about familiarity } \\
\text { with ICT }\end{array}$ \\
\hline $\begin{array}{l}\text { Skype/phone calls from } \\
\text { UK to Zambia }\end{array}$ & $\begin{array}{l}\text { On average, one call with } \\
\text { facilitator per week }\end{array}$ & $\begin{array}{l}\text { Workshop planning and follow- } \\
\text { up, logistics, feedback from } \\
\text { CPD leader (Abel) } \\
\text { Discussion, joint planning of } \\
\text { CPD resource }\end{array}$ \\
\hline
\end{tabular}

Table 1. Overview of OER4Schools Phase 3 data collection

Lesson observations and recordings. The teachers clearly made an effort in planning and preparation (for observed lessons with and without video recording), and thus there was evidently a degree of reactivity. Nevertheless, lessons observed towards the start of the programme (March) were still fairly close to a typical rote-learning lesson. Towards the end (October), we co-planned lessons with the teachers, in order to support them in teaching the most interactive lessons they were able to, for filming purposes. ${ }^{2}$ Four teachers were also filmed teaching in January before the programme began; these baseline videos confirmed that pedagogic practice in the school was typically transmission based.

Interviews. Semi-structured interviews were carried out individually with 7 teachers and the main facilitator in March 2012, about 10 weeks after the programme started. At the end of the school year (November), three further group interviews were conducted, involving 8 teachers, plus an additional interview with the facilitator. The prompts solicited participants' experiences and perceived outcomes of participation in the programme, opinions about interactive teaching, perceived change within their own practice (requesting concrete examples), and challenges experienced. All interviews were transcribed in full.

Post-lesson audio reflections. Teachers were asked to conduct and reflect on at least one lesson per week that was based on the OER4Schools programme. Detailed audio diary guidance was provided concerning what to reflect on, such as: the topic taught; the interactive techniques and resources used; the teacher's expectations of the strategy chosen for that specific class; the outcomes observed; the positive or negative aspects of the experience (for teacher and pupils) as a whole; whether technology (if used) contributed to the achieved outcomes; what might be done differently next time; and any other comments teachers had on how they were getting on with new teaching techniques.

${ }^{2}$ The filmed lessons from October 2012 are available at http://oer.educ.cam.ac.uk/wiki/Video. 
A strength of the diary method was the more 'active participation' of research respondents (Holstein and Gubrium, 1995) whereby individuals offered constructions of personal experiences and insights they perceived to be important, with less evident shaping of those constructions through interaction with peers or researchers (Holly, 1987). Since the researchers were located at a distance, diaries facilitated more frequent reporting than would have been possible otherwise. Audio diaries were intended to make the process of reflection simpler by removing the need to write. Teachers initially tended to write down what they wanted to say first, but later, with more confidence, started to record reflections more freely. Nevertheless, they recorded fewer reflections as the year progressed.

Portfolios. Teachers were given very concrete guidance for developing their portfolios. The guidance asked teachers to reflect on actual classroom activities, to show how they were putting what they had learnt into practice. We emphasised that the portfolio was not intended to test teachers' knowledge of certain techniques), but to showcase what they had achieved, and how their thinking and practice had moved on. When portfolios were submitted, we provided feedback, both on the portfolio itself, as well as constructive feedback on the teacher's professional development. Despite the guidance given, only some of the actual portfolios and reflections received (in line with current teacher college practice) featured concrete examples of classroom teaching; others instead summarised topics from the resource. There was also some resistance to doing the portfolios, which was reportedly due partially to teachers' lack of confidence and familiarity, and needing more guidance. It may also be that teachers did not understand the importance of the portfolios, and did not complete portfolios for that reason. Teachers were expected to audio reflect on the portfolios, and again, concrete guidance (and examples) was provided.

Phone calls from the UK to Zambia. Phone and Skype communication was seriously constrained by poor audio and handset quality, and connectivity. More often than not, calls were limited to essential logistics.

\subsection{Analysis}

Our analysis focused on the opportunities and outcomes of teachers' professional learning and pedagogic change during the programme. The data described above were scrutinised to identify general themes and areas of rich content, as well as emerging puzzles and speculations for testing further, through a process of cross-sectional indexing (Mason, 2002), whereby a coherent system of categories was developed during the analysis and applied across the data set. This process involved both prior literature and close examination of the data itself. Abstraction from the research literature and our prior studies yielded some insights into the kinds of change that this form of professional development might stimulate; we sought to test and validate these and at the same time we examined the data to explore further outcomes and perceptions. The data were coded twice, first to refine the categories and allow new ones to emerge, then again to systematically code the dataset. NVivo10 software was used to assist in this second round and to run further reliability checks through text and coding queries as well as returning to a subset of data to code it again to check consistency. Groundedness of the categories was explored prior to interpretation by systematically examining the spread of the discussions across the participants and data sources. 
Two broad principles guided the analysis and interpretation of the coded content. Firstly, systematic steps were taken to ensure the data were comprehensively included in the analysis, beyond individual 'telling' examples. The talk on different aspects of the programme and/or pedagogic change was examined through comparing the content of the participants' talk and writing, to examine specific ideas about pedagogic change and its challenges. The emerging ideas were systematically compared across participants and datasets: hereby we purposefully sought discrepant and unclear examples to test the trustworthiness of our interpretations (cf. LeCompte and Preissle, and Tesch 1993; Silverman, 2015). Such discrepancies are illustrated in our account below.

Secondly, we systematically focused on examining the extent to which teachers' accounts could be considered to present evidence of actual pedagogic change, rather than simply evidence of fluency in a (new) pedagogic discourse. Particular emphasis was thereby put on examining whether teachers' accounts of change were substantiated by concrete examples of classroom practice and only such accounts formed the basis of the findings reported. In other words, we focused on the meanings these teachers gave to concrete classroom events and incidents rather than simply their talk about pedagogic ideas (Hofmann, 2008). As ideas were refined in this process, we regularly returned to the original data to test for further occurrences/counter-occurrences in the data.

\section{Findings and discussion}

\subsection{Accounts of pedagogic change across the data}

There are two main pedagogic changes that we distilled from the teachers' accounts: making space for more pupil-led talk and exploration of topics and ideas, and building on pupils' prior knowledge. In this section we draw on examples from both interviews and workshops to illustrate.

\subsubsection{Shifting from lecturing to increased opportunities for pupil talk and exploration of ideas}

The first broad pedagogic change constructed in the teachers' talk is moving away from solely teacher lecturing, whereby the pupils' task is to provide correct answers to questions; Judith described her class as previously "just dormant and listening”. Instead, teachers suggest they are increasingly encouraging children to share ideas.

When I wrote the talking points on the chalkboard, ten of them, then I divided the class [in mixed groups]. So they were supposed to give the reasons for saying true or false. Only one group managed to do that because of the language barrier but these others were able to tell in Nyanja. [...] The difference [compared to the year before OER4Schools] is that they were really in groups, they were able to share their ideas, not where they are supposed just to listen to the teacher, the teacher talks, talks, talks and gives the work, you do this, and they write and we mark you know, but [when using group discussion] there's a change whereby they [discuss and] change their ideas, see? (Miriam, Nov12)

They are also letting children lead activities and find information on their own, as in the following quote: 
I liked inquiry-based learning because it's not like whatever we teach is supposed to come from the teacher. So this inquiry-based learning, it helped me and my pupils when we want to discover something, for instance when we went out for the field trip. We didn't tell them what we are going to find in the bush ... This time they were able to go there and find out for themselves, not me telling them to say 'go out and look for this'. They were able to see the snakes, they were able to see the insects, they were able to see different types of fruits in the field, which was very helpful. (Bernadette, Nov12)

In another inquiry lesson, we can see Aggie challenging pupils to make predictions (in groups) for various quantities related to fitness (e.g. lung capacity), prior to doing experiments: http://oer.educ.cam.ac.uk/wiki/Video/Aggie Fitness_A04.m4v.

And, Judith can be seen gathering pupils' ideas on what makes us healthy in this clip: http://oer.educ.cam.ac.uk/wiki/Video/Judith body A01.m4v

The research reviewed above has suggested that the use of whole class and group work, where students discuss a shared task, was one of the effective teaching strategies that is more likely to impact student learning outcomes in low-income countries (Westbrook et al., 2013) but also that it is rare in Zambian education, which is normally focused on a transmission-based model of teaching and superficial rote learning (e.g. Carroll, 1996; Morrow et al., 1998). Therefore, this teacher talk, warranted by concrete examples of practice, suggests a potentially important change. What was further argued is that using such strategies in a way that focuses teachers' attention on pupils' learning and understanding is central. This is particularly visible in the second theme below.

\subsubsection{Building on learners' prior knowledge}

The second pedagogic change constructed in the teachers' talk is checking on children's existing knowledge or understanding and adapting teaching accordingly, that is, scaffolding learning. The elements of the OER4Schools programme that feature in these accounts of change as enabling factors of these changes are: Questioning strategies, Inquiry, Brainstorming and Assessment for

\section{Learning.}

I would say the most significant change is maybe the issue of brainstorming ... I really benefited from that. That's a very, very good concept to be used as you are teaching, because you don't just go into a room or a classroom and then say 'today we are talking about this', and then you tell them just everything. So I really made it a point that every time I introduced a topic, I used brainstorming so that I know where to start from: What is it that the children know about a particular topic? (Priscillah, Nov12)

She elaborated with a concrete example:

I remember one time I was teaching about AIDS. I simply said 'can you write, I'm going to give you five minutes to think about things that you know about AIDS'. They brought in a lot of issues you know. 'Oh AIDS is transmitted like that, AIDS stands for this that, you know.' So all those really taught me a lot of things, I realised children know something. So when I tell them to brainstorm, they should be able to tell me what they know about a particular topic, and then as a teacher, I will know where to start from. And like that, they don't forget easily. So it's actually one of those things, one of the aspects that I'd really ignored before coming in on the programme. (Priscillah, Nov12) 
Priscillah can also be seen using the technique in another context — brainstorming about different soil types prior to starting a new topic on soil - in this clip:

http://oer.educ.cam.ac.uk/wiki/Video/Priscillah Water Soil A01.m4v.

The teachers are describing having learned a new strategy of drawing on pupils' prior knowledge, backgrounds and experiences. What is important here is that this strategy is not used solely to manage pupils' attention but in a way that focuses the teacher's attention on the learners, their knowledge and understanding. Moreover, having used this strategy in such a way, it has enabled the teacher to notice something new, to see her pupils and their capabilities in new ways: I realised children know something.

Such changes create additional work for the teachers, of course, stretch their resources and can even be seen as risky. We should therefore consider how these teachers view the possible benefits of pedagogic 'experiments' they undertook.

\subsection{Teachers' perspectives on the impact of pedagogic changes for pupils' learning and engagement}

The pedagogic changes are described in the teachers' accounts as having effected various improvements in the pupils' education (most of which are described through at least some concrete examples, by some teachers), and as impacting on pupil enjoyment, classroom atmosphere, pupils' engagement in classroom learning and actual learning.

\subsubsection{Pupils' engagement in classroom learning and classroom atmosphere}

The teachers describe enhanced pupil enjoyment and a positive classroom atmosphere during the programme activities.

When we did [the field trip], pupils were very much excited when we went out there. (Bernadette, Nov12)

In mathematics, I was doing fractions, and I gave them group work, then I went round checking what they were doing and they were helping each other and they were excited, they were [checking] each other's [work], like 'no it's not supposed to be like that, here it's supposed to be this', yes, so that was good. (Susan, Nov12)

Given the challenges some of these pupils face in their lives outside school, including poverty and lack of parental support for their school work, helping them enjoy learning activities in school is not insignificant. Moreover, as in the above examples, the teachers are not only talking about pupils being entertained by the programme but pupils' engagement in the classroom activity.

Pupils can be seen working in groups using calculators and recording data on netbooks - actively engaged in the task — in this clip: http://oer.educ.cam.ac.uk/wiki/Video/Judith body A11.m4v. Despite their reluctance to contribute to pre-experiment questions, pupils confidently discuss (in their local language) the results of an experiment - investigating the efficiency of different methods of hand washing — in another clip: http://oer.educ.cam.ac.uk/wiki/Video/Judith.m4v. 
Enhancing pupils' enjoyment of, and engagement in, classroom activity also applies to those who are not traditionally seen as strong learners, such as pupils who do not speak English (often the language of instruction):

I think the most valuable [technique] is that of letting my children sit in their various groups, of course, of mixed abilities. Then you let them do most of the work. ... So, I feel that is great because that way those previously not speaking, are active participants now and they look forward to being given work to do in groups.

[The most significant change that I noticed in my practice so far, is that] Most of the pupils have improved. Let me just say, participation in class has really improved. [Previously] I relied on very few children to give me answers, but this is different. I have seen a lot of them participate, you know. At least they try, by all means, even if what they'll give you is wrong but they are able to talk, and I feel everything starts from there. (Priscillah, Mar12)

These experiences are also reflected in the teachers' audio reflections. What is described in the stories by the teachers are characteristics of a safe and inclusive classroom culture in which pupils help each other and are increasingly confident to contribute even if they are not strong on some of the formal criteria of school success. For example, Judith encourages an inclusive classroom culture, guiding pupils to help each other to discover the source of an error, in this clip: http://oer.educ.cam.ac.uk/wiki/Video/Judith body A08.m4v.

\subsubsection{Pupils' learning}

The teachers also repeatedly make reference to pupils' learning, in terms of not forgetting what they have learned and gaining deeper understandings of subject matter based on their active engagement in the programme activities: "it will remain in them; they will never forget what they did"; "the use of experiments should really be emphasised, so that children don't easily forget what they learn."

While the teachers make no reference to external evidence for these statements on pupils' learning, such as the usual assessments they use, they report regularly checking on learners' understandings by observing pupils during group work, and asking questions to explore pupils' knowledge, with examples from concrete tasks:

I know they've learned something because sometimes I ask them to present randomly and everyone is ready to present to the whole class, so, I have no problems now because they all present and if they can't present then I know that they haven't learned anything. But for this class, everyone was ready to present something. (Aggie, Oct12)

Above, we can see the teachers reporting on pupils' enjoyment of the programme activities, enhanced and widened pupil participation in, and contribution to, classroom activities, as well as signs of thoughtful pupil engagement with the topics of learning. These are constructed in the teachers' stories as emerging from the increased opportunities for pupil initiative, exploration and collaboration in the learning activities, and decreased amounts of authoritative teacher talk, in turn 
supported by collaboration with colleagues. Throughout the data, these stories also include surprise about what the children came up with and were able to do:

I could see what they really came up with, especially when we conducted the experiment [about soil]. They have learned that previously, but we didn't conduct any experiments. After conducting that, especially on water retention itself, they were able to investigate water retention using different amounts of soil, as well as using different types of soil. After they had done that I remember we asked certain groups to report their findings. It was so interesting to see. Even those that don't take part actively in the lessons, they were able to do it when we conducted the experiments because they were able to give out correct findings. I remember one girl could say ... 'water retention is all about different amounts of soil'. I asked them . . . looking at what you've collected and everything, so what does this show? The girl was able to say, 'this really shows that the more amount of soil you have ... the higher the water retention'. So, I found it so interesting, because I didn't imagine that girl, actually, could take part, could actually explain like that. So, to me, it was a surprise. (Priscillah, Oct12)

This illustrates how, even if the teachers may sometimes initially implement new teaching strategies that are considered potentially beneficial in more formulaic ways, their very implementation may enable the teacher to come to see their pupils and their capabilities in new ways. This thereby potentially supports a stronger focus on pupils and their learning and understanding (Haßler, Hennessy \& Hofmann, in press). It leads us to the important issue of the teachers' perceptions of their pupils.

\subsection{Teachers' perceptions of their pupils' knowledge and learning}

In addition to reports of changes in the practices of teaching and learning, there are accounts of change in the data which signal changes in the teachers' ways of viewing their pupils and their opportunities, knowledge and capabilities. In the teacher interviews towards the end of the programme, a shift is perceptible in their accounts:

Maybe I can't use this term but we underrated them. . . . But Leadership for Learning, it was very nice. To me, I discovered that three quarters of my class they are able to be leaders, yes. Even [when] somebody says 'she is young, she cannot do it', they have that capacity and they showed it when we were doing those topics, yes ... Maybe we were doing it just on the surface [before], but after doing this we were really deep into it and even knew how to express things and how to really involve. In Zambia we are saying lessons should be pupil-centred. But sometimes we say, 'this topic is too hard for the pupils, I cannot just leave them to do it alone. It'll be there like, too much'. But after doing inquiry-based [activities], leadership for learning and the assessment [for learning], it's just, it's bringing out that the pupil can do anything. (Aggie, Nov12)

She elaborated with a concrete example from having her lesson filmed: see the resulting clip (http://oer.educ.cam.ac.uk/wiki/Video/Aggie lung capacity.m4v). 
I confessed to him, I said, Bjoern [researcher], I think I failed, choose somebody else to

film. I was looking at the activities and comparing it to my pupils, so I said no, this is too much, and I won't manage. And the pupils themselves, they won't manage to do all these things. So he says no, you cannot fail now, you will fail when you [give up]. So I said okay fine, let me try to do it. So I prepared and went to class . . . it was just smooth, yeah I just gave a command and they were all there doing it, checking the lung capacity. They didn't forget to record [or] how to make graphs on their netbooks. . . . So at the end of it, I said okay now I can say I'm successful! [Aggie, Nov12]

Above, Aggie directly acknowledges the challenge, discussed in the workshops, of teachers typically believing that their pupils are not able to work in these ways and then finding out that, given the opportunity and support, they can. Judith reinforces this:

Before I used to underrate children saying that I've got to keep on lecturing, [pupils] just listening, [and] after teaching, then that's when I ask questions - without [giving] them a chance to think on their own before I summarise[d] everything. But after this programme, I first tell them . . . this is what I expect to get, [these are] the [lesson] objectives. So can you do this on your own? So on their own they are able to find answers and thereafter tell them to me. (Judith, Nov12)

She elaborates through an example:

When asking 'What do you think would be the good part of plants to us human beings?,' a lot of answers came up, such that I also learned something from there. There is one child who even mentioned it is also medicine. . the thing that impressed me was, the child mentioned a certain tree ... which can be used [to treat illness] so I was very very happy. And this programme has really changed even the way I teach children. Children now know. They know what is to be done. (Judith, Nov12)

What the above stories suggest is a shift not only in the teachers' perceptions of the children's capabilities to learn, but of the knowledge the children bring to school from their own communities, however poor, and the value of that knowledge (cf. Haßler, Hennessy \& Hofmann, in press). This is related to the notion of "citizen science" (Roth and Lee, 2004) and while we have limited data relevant to this, it confirms that the intended links to everyday knowledge encouraged by our programme were beginning to become evident. Moreover, these stories illustrate that teachers' new observations have begun to challenge the shared local norms and beliefs that have guided their practice. This is not only true for individual teachers and their observations, but more collectively so, as can be seen in the pair interview with these two teachers, Judith and Aggie; they discuss this together at length, each contributing their own examples to challenge the existing views.

\subsection{The perceived challenge of pupil participation}

However, despite the very positive observations with many pupils, teachers are concerned that not all children are participating, particularly due to limited ability to speak English. Although Zambian policy envisages use of local (official) Zambian languages alongside English (especially in lower grades), many teachers do not speak the same languages as all of their pupils and there is often a preference for giving instructions in English. Consequently, one group of pupils whose participation 
the teachers are concerned about is those whose English competencies are weak. Pupils' language skills are of course pertinent to their learning, and key to improving their lives. Through sharing and discussing ideas, group work gives children an opportunity to practice their skills in the local official language (Nyanja). Some teachers reported that by encouraging the use of the languages pupils are most familiar with, they were able to engage those pupils in discussion, and thus support their learning.

However, some teachers also managed to engage children in speaking English — despite limited English language skills. Such opportunities to engage in actively speaking and discussing (in English) — rather than just passively listening — supports those pupils' development whose spoken language skills (including English) are weak and who do not have opportunities to rehearse English outside school.

In this clip, one pupil is leading the discussion in English (with hand gestures) and the other pupils are listening intently and trying to keep up, asking for clarification in their own language: http://oer.educ.cam.ac.uk/wiki/Video/Judith body A24.m4v.

However, the concern remains that some pupils are not participating in interactive lessons, even when encouraged to use languages they are strong in:

Not all learners participated. Others were participating but they didn't know what they were doing ... [they] were just dormant, looking at their friend and even if you go there and tell them, do this, he could hold up this [show them] but they couldn't not get anything from it. - Those who have not learned anything, even if you ask them, even if you tell them to use their local languages, they were failing to explain. So, you can tell that they have not learned anything. (Agness, Oct12)

In the following clip, Judith struggles to engage all pupils in the discussion task; they are reluctant to discuss their experimental findings: http://oer.educ.cam.ac.uk/wiki/Video/Judith body A21.m4v.

One possible explanation for this reluctance is that pupils do not properly understand their results and the way that they have been encouraged to record them (it is clear from analysis of the completed worksheets that a number of pupils were unable to calculate the average of their results or to identify 'outliers'). This may have made it more difficult for them to make sense of, and therefore discuss, their results, thus contributing to the perceived lack of participation. Based on analysis of other parts of the data, we suggest that this may not primarily be a matter of weaker pupils struggling more with the kind of discursive activities introduced by the OER4Schools programme, compared to what the teachers were doing previously. It may be that a way of working that emphasises pupil initiative and independence actually makes the struggles of weaker pupils more visible to the teachers. One of the teachers, Bernadette, mentions in her audio reflections how using Assessment for Learning strategies "illustrates the strengths and weaknesses of the learners." She adds that

The Questioning strategy is used throughout the lesson as the teacher is trying to find out what the learners have got to know and what they should know. It worked well when I needed oral feedback from the learners. This technique is so good because it helped me to 
evaluate the lesson, myself as well as the pupils, before I could even finish teaching the lesson. It also helped me to change my approach if the learners were not with me.

Other teachers discuss this with concrete examples from their practice:

What I learnt from [the traffic lights ${ }^{3}$ ] is that I was able to identify the slow learners and those who needed help [and also] learners who were just copying from their friends.

(Martha, audio reflections, July12)

Nonetheless, observing such struggles with pupils may be perceived by teachers as reinforcing existing assumptions about pupils and thereby existing norms and forms of practice. It is also clear that conscientious teachers will be concerned about enabling all learners to participate.

\subsection{Increasing participation of all learners}

In an earlier phase, teachers spontaneously debated the merits of different grouping strategies in a workshop. Afterwards, one teacher (Agness), who had reported that her low-attaining 'Banana' group struggled with a mathematics task, consequently devised a successful lesson plan based around mixed pace groups and activities requiring students to explain a concept to each other, groups to set problems for each other and to mark each other's responses (Haßler, Hennessy \& Cross, with Chileshe \& Machiko, 2014). A number of teachers developed their understanding of the benefits of mixed pace grouping. In Phase 3 (reported here), similar debates took place, and Judith comments that:

I have learnt from that to say, so those if they remain like that [slow learners together], they will remain like that forever. They can never learn anything from others. So the best I can do, just the way we have been discussing, to say, it's better to mix them so that, at least, even them can learn something from the rest of the group. (Judith, March 2012)

Further details of Judith's experiences and her peers' responses are available at http://www.oer4schools.org/Mixed pace groupwork with and without ICT.

However, while the introduction of mixed pace group work is one of the key changes in classroom practice that came about because of the programme ${ }^{4}$, some contradictions between teachers' accounts were apparent. For instance, while in the interviews the teachers discussed 'same task' mixed pace grouping within their classrooms very positively, in the workshops (earlier on), among the teachers themselves, critique and doubt were expressed:

I think the low achievers, you have to put them together - so that you give them the simplest topic so that at least they can tackle that topic according to their level. Once you give them the work according to their level and they get everything they get to be motivated and they will put much effort on that but if always you give them tough work with faster learners, always they will be - demotivated. [Unit 4.3 workshop]

\footnotetext{
${ }^{3}$ Traffic lights are colour-coded cards displayed by students on their desk to discreetly indicate to the teacher their self-assessed current level of understanding; they are a key strategy in Assessment for Learning.

${ }^{4}$ Zambian education policy has subsequently changed, and mixed pace grouping is now required.
} 
Other similar contradictions are present in the data. In the interviews the teachers are very supportive of the programme as suitable for all learners; in the workshops a teacher expresses a critical view, suggesting that 'our type of children' are not able to learn in learner-driven ways (for detailed discussion, see Haßler, Hennessy \& Hofmann, in press). There are also discrepancies in the teachers' views of whether it is possible for them to implement all aspects of the programme in light of Government requirements, particularly as conveyed through school inspections. Both in the interviews and workshops, teachers happily discuss their use of brainstorming without concern, yet some teachers express concern in the interviews that brainstorming would not be perceived favourably by inspectors:

I think personally, I would not continue telling the kids about brainstorming, I wasn't comfortable with that. (Martha, Nov12).

(Agness continues:) Even if the inspectors if they have come, because this is not taught in Zambian context, I think you can be questioned that 'why are you saying that now it's time for brainstorming? ... Where have you learned this, which lecturer, which college?' You know, they do talk! So as she has said, even I was not comfortable.

We have deliberately sought to test teachers' interview comments across the data to probe whether they are grounded in examples of actual pedagogic practices rather than merely more proficient engagement in a particular pedagogic discourse 'performed' in the interviews. The narratives presented throughout this article illustrate the warranting of teachers' comments by concrete examples. It is, however, not surprising that there should be a multiplicity of views with regard to some issues when problems in and changes to current established practice are at stake. Rather, this should be expected.

\section{Conclusions}

The overarching goal of our OER4Schools programme is to contribute to increasing the quality of primary education in SSA (UNESCO, 2014), beginning with Zambia where there is very little prior research or contextualised CPD material. We acknowledge that the conditions for teaching and learning in typical SSA classrooms are in many ways challenging. These challenges notwithstanding, our study presents clear evidence of teachers' trialling and implementing new pedagogic strategies in the Zambian classrooms studied. Changes included teachers moving away from lecturing monologues and instead building on pupils' prior knowledge, differentiating and scaffolding development of new knowledge. This enabled teachers to tailor their classroom activity appropriately, either revisiting topics as necessary or moving forward where goals have been achieved. Teachers were found to create more space for pupil-led talk, allowing deeper exploration of topics and encouraging children to share their own ideas. They described increased engagement from pupils who are not considered strong learners, in the context of a safe and inclusive classroom culture, in which pupils help each other and are increasingly confident to contribute. There was a marked shift towards mixed pace grouping.

However, it would be incorrect to suggest that all the stories emerging from our research were 
consistent throughout the data. While some teachers were happy to implement all aspects of the programme (and recognised its potential), we have illustrated how other teachers were not as comfortable. On the other hand the very discrepancies between teachers also suggest that there is always scope for some movement and different interpretations. For despite the workload and demands of time, teachers emphasised the significance of their engagement with the programme:

We need to really come up with very good time[tabling] to accommodate it, and it should really suit, because this [programme] is very beneficial to both teachers and pupils, you cannot just let it go like that. (Aggie, Nov12)

(c.f. also Haßler, Hennessy \& Hofmann, in press).

The literature review (Section 1.3) suggested that opening up new opportunities for teachers to focus on pupils and their learning and understanding is a critical feature of professional development. Our analysis suggests that while initially some of the strategies may inevitably have been implemented in a more formulaic way, the programme ultimately achieved this shift. The findings additionally show that teachers reported improvements in learners' understanding, which they facilitated by asking questions to explore their knowledge and assessed by circulating and observing pupils during group work. This is significant, as Zambian teachers conventionally sit at their own desks during group work tasks (or supervise another class). It contrasts with the study of Nsibande and Modiba (2012), where such deeper probing did not take place. Further evidence for teachers' evolving insight into learners' understanding came from the teachers' comments and surprise that the children are able to make significant progress in learning, indicating that their traditionally low estimation of children's capabilities was challenged, and that teachers' perceptions of their pupils were shifted.

While the sustainability of these changes is the focus of a later paper (Haßler, Hennessy \& Hofmann, with Makonga, forthcoming) requiring longitudinal data, many of the teachers themselves suggested here that these new observations about their pupils have made them want to use such strategies. This suggests an iterative process of implementation and professional learning whereby implementation may enable opportunities for noticing things that can lead to professional learning, which again may in turn support further implementations (van Es and Sherin, 2008), rather than a model whereby professional learning precedes implementation.

Teachers seeing new opportunities, and perceiving new classroom applications as possible, is central to take the 'leap of faith' required for change. Noticing the effects of trying something new is also important for more sustained change (ibid.; Rainio \& Hofmann, 2015). An interesting question here is whether the new observations arising through trialling new pedagogic strategies can lead to challenging the shared values and norms of practice of the local setting (cf. Watson, 2014). Can these new observations impact and support the emergence of a new 'reality' for enacting subsequent professional practice that can enable and sustain such change? There is some evidence of spreading and sharing of the newly emergent observations and ways of thinking among the teachers in this study that may pave way for these new observations to begin to shape thinking and guide practice in this context more widely. Besides, we argue, based on Watson's (2014) discussion, that rather than being problematic, the reported discordances in the pedagogic values and perceptions among some teachers can potentially trigger change. Our findings confirm the 
importance of facilitation in bringing out this dissonance and of conducting further research into how facilitators can effectively mediate such discussion.

There are of course significant sociocultural constraints operating in this context, including the prevalent ones outlined in Section 1 (e.g. lack of resources, the disadvantaged backgrounds of pupils, and absenteeism). In this paper we have reported the outcomes that the programme achieved despite the challenges, owing to its careful contextualisation for Zambia. Teachers also became more aware of the real struggles of some learners. Previously, pupils may have quietly dropped out, or performed poorly in exams. Teachers developed greater awareness of all learners' progress, further highlighting issues surrounding pupils from often exceptionally challenging backgrounds.

Although Ngware et al. (2014) did not clearly distinguish between interactive and non-interactive classroom practices observed, we suggest that it may well be the case that particularly the interactive parts of the practices observed in their study lead to learning gains. Our approach shares similarity with the TESSA programme, and corroborates their findings (Wolfenden et al., 2010, Power 2013). Like Pryor and Westbrook (2013) and Moyo and Modiba (2014), we emphasise a practice-based teacher education curriculum, with practicum rescheduled so it is not just about "trying out" but is the main resource for college-based learning. Shifting the focus from telling to listening requires such sustained professional development geared towards developing teachers' skills at listening and interacting, and takes time (Suurtamm and Vézina, 2010, Carroll et al., 2000).

\section{Outlook}

We strove to meet the challenge posed by Stein et al. (1999) of achieving a balance between providing sustained support to the school without establishing overdependence on ourselves as "outsider" researchers; the aim was to create a self-sustaining community of inquiry within the school. One of our facilitators vividly described a discussion at a staff meeting towards the end of 2012, where teachers of the lower secondary phase criticised the reading skills of the pupils moving from primary into lower secondary. As part of the discussion, teachers proposed that perhaps it was not the pupils who are at fault, but that there was scope for improving teaching and learning overall at the school. They suggested that the OER4Schools programme should not only continue, but also be broadened to include all 12 grades, involving all 35 teachers. This proposition was accepted and implemented. As researchers, we were immensely encouraged by this spontaneous and autonomous decision to continue and to extend the programme. The OER4Schools programme moved into Phase 4 in January 2013. It was adjusted to a two-year programme with bi-weekly teacher group meetings, to reduce the demand on teachers. The resource was further developed and revised throughout 2013. It continues to run in a self-sustaining manner, facilitated largely by teachers who participated in earlier phases.

An important consideration is the wider scalability of the programme to other schools in Zambia and, indeed, elsewhere. A potential model could include regional development leaders, who could be school cluster-based. Of course, in SSA, the challenge is to achieve high-quality outcomes of CPD with very limited financial resources. While such considerations were not the focus of this 
paper, they are discussed in a forthcoming publication (by Haßler, Hennessy \& Hofmann, with Makonga) examining scalability, sustainability and the wider setting beyond the school (community, policy: Tikly, 2011). Another article outlines the infrastructural, cultural and teacherlevel factors influencing introduction of new forms of professional development, teaching and learning and uses of digital technology (Haßler, Hennessy \& Hofmann, in press).

We continue to develop and research the resource, including collaborating with a number of African institutions, and making adaptations for pre-service, and university/college-based in-service provision (Hennessy, Dreyer, Paulsen, Haßler, Loubser, Beardon \& Mays, 2014). Together with Kenyan scholars and teachers, we are presently recontextualising for Kenya. We believe that our research shows that OER4Schools, in partnership, could be the basis of an effective programme for in-service teacher professional development across SSA. Interactive pedagogy, OER, and digital technologies can reinforce each other and promote professional learning for teachers, and pupil learning and engagement. In conclusion, in the same way as Zambian teachers are surprised by the "abilities" of their pupils, and are willing to re-consider their views of what pupils are capable of, perhaps we should also reconsider our assumptions of teacher capabilities, and be surprised and humbled by what a group of Zambian teachers was able to achieve.

\section{Acknowledgements}

We are most grateful to the teachers and the school who participated in our trials. Thanks also to Melissa Marsden for her role in the data collection and analysis, and to the anonymous reviewers who provided helpful feedback on an earlier draft of this paper. The OER4Schools programme was based in the former Centre for Commonwealth Education (CCE) at the University of Cambridge and was funded by the Commonwealth Education Trust between 2009-2014. We greatly appreciate the administrative support provided by various CCE staff throughout the programme.

\section{References}

Antoniou, P., \& Kyriakides, L. (2011). The impact of a dynamic approach to professional development on teacher instruction and student learning: results from an experimental study. School Effectiveness and School Improvement: An International Journal of Research, Policy and Practice, 22(3), 291-311. http://doi.org/10.1080/09243453.2011.577078

Avalos, B. (2011). Teacher professional development in "Teaching and Teacher Education" over ten years. Teaching and Teacher Education, 27(1), 10-20. http://doi.org/10.1016/j.tate.2010.08.007

Pol, J. van de, Volman, M., \& Beishuizen, J. (2010). Scaffolding in Teacher-Student Interaction: A Decade of Research. Educational Psychology Review, 22(3), 271-296. 
http://doi.org/10.1007/s10648-010-9127-6

Buckler, A., \& Gafar, A. I. A. (2013). Professional Development and Female Teacher Morale in Rural Communities. In B. Moon (Ed.), Teacher Education and the Challenge of of Development: a Global Analysis (pp. 115-128). New York: Routledge.

Butler, D. L., Lauscher, H. N., Jarvis-Selinger, S., \& Beckingham, B. (2004). Collaboration and self-regulation in teachers' professional development. Teaching and Teacher Education, 20(5), 435-455.

Carroll, W. M. (1996). Use of invented algorithms by second graders in a reform mathematics curriculum. Journal of Mathematical Behavior, 15(2), 137-150.

Carroll, W. M., Fuson, K. C., \& Diamond, A. (2000). Use of student-constructed number stories in a reform-based curriculum. The Journal of Mathematical Behavior, 19(1), 49-62. http://doi.org/10.1016/S0732-3123(00)00038-9

Cochran-Smith, M., \& Lytle, S. L. (1999). Relationships of knowledge and practice: Teacher learning in communities. In A. Iran-Nejar \& P. D. Pearson (Eds.), Review of Research in Education (Vol. 24, pp. 249-305). Washington, DC: American Educational Research Association (AERA). Retrieved from http://www.jstor.org/stable/1167272.

Coles, A. (2012). Using video for professional development: the role of the discussion facilitator. Journal of Mathematics Teacher Education, 16(3), 165-184. http://doi.org/10.1007/s10857-012-9225-0

Cordingley, P., Bell, M., Rundell, B., \& Evans, D. (2003). The impact of collaborative CPD on classroom teaching and learning: How does collaborative Continuing Professional Development (CPD) for teachers of the 5-16 age range affect teaching and learning?. London: Evidence for Policy and Practice Information and Co-ordinating Centre (EPPICentre): Social Science Research Unit, Institute of Education, University of London. Retrieved from https://eppi.ioe.ac.uk/cms/Default.aspx?tabid=132

Cordingley, P., Rundell, B., Temperey, J., \& McGregor, J. (2004). From transmission to collaborative learning: Best evidence in continuing professional development (CPD). Presented at the International Congress for School Effectiveness and Improvement (ICSEI), Rotterdam, The Netherlands.

Cornford, I. R. (2002). Reflective teaching: Empirical research findings and some implications for teacher education. Journal of Vocational Education \& Training, 54, 219-236.

Duffin, J., Marland, H., Wooldridge, D., Garrard, W., Jaworski, B., Tyson, A., \& Young, R. (1991). Develop Your Teaching. Cheltenham: Stanley Thornes.

Glewwe, P., \& Kremer, M. (2006). Schools, teachers, and education outcomes in developing countries. In E. Hanushek \& F. Welch (Eds.), Handbook of the Economics of Education (Vol. 2, pp. 945-1017). Elsevier B. V. Retrieved from http://www.sciencedirect.com/science/article/pii/S1574069206020162

Hennessy et al. (2015). Pedagogic change ... - 28 
Haßler, B., Hennessy, S., \& Hofmann, R., with Makonga, A. (forthcoming). Sustainability and scalability of pedagogic innovation in sub-Saharan Africa: The case of the OERS4Schools professional development programme.

Haßler, B., Hennessy, S. \& Cross, A. with Chileshe, E. and Machiko, B. (2014). School-based professional development in a developing context: Lessons learnt from a case study in Zambia. Professional Development in Education.

http://dx.doi.org/10.1080/19415257.2014.938355

Haßler, B., Hennessy, S., Lord, T., Cross, A., Jackson, A., \& Simpson, M. (2011). An investigation of appropriate new technologies to support interactive teaching in Zambian schools (ANTSIT). A joint report from Aptivate and the Centre for Commonwealth Education (University of Cambridge). Final Report to DfID. Cambridge: Aptivate and University of Cambridge. Retrieved from http://www.educ.cam.ac.uk/centres/cce/initiatives/projects/antsit/

Haßler, B., Hennessy, S., \& Lubasi, B. (2011). Changing classroom practice using a school-based professional development approach to introducing digital resources in Zambia. Itupale Online Journal of African Studies, 3, 17-31.

Haßler, B., \& Mays, T. (2014). Open Content. In P. Hwa Ang \& R. Mansell (Eds.), International Encyclopedia of Digital Communication and Society. Wiley-Blackwell. Retrieved from http://bjohas.de/Publications/Hassler Mays OpenContent

Hennessy, S., Dreyer, J., Paulsen, R., Haßler, B., Loubser, C., Beardon, T., \& Mays, T. (2014). Professional learning with ICT in the southern African context: The UNISA-Cambridge collaboration on Advanced Diplomas in Education. Prezi presentation at $5^{\text {th }}$ Higher Education \& ICT Summit: 21st Century Learning and Collaborative Teaching, Johannesburg, South Africa. Retrieved from http://tinyurl.com/2014ICTsummit

Hennessy, S., Haßler, B., \& Hofmann, R. (2015, in press). Challenges and opportunities for teacher professional development in interactive use of technology in African schools. Technology, Pedagogy and Education 24(5). Special Section on "Capacity Building for 21st Century Learning in Africa: A Focus on ICT Integration in Education” edited by J. Tondeur \& J. Voogt.

Hennessy, S., Haßler, B., \& Mwewa, G. (2012). Using digital technology and school-based professional development to leverage interactive classroom teaching in Zambia. In J. MacBeath, M. Younger, \& C. Sugrue (Eds.), Millennium Goals Revisited: A Common Wealth of Learning, (pp. 35-48). London: Routledge.

Holly, M. L. (1987). Keeping a personal-professional journal (Rev. ed.). Victoria, Australia: Deakin University Press.

Hofmann, R. (2008). Ownership in learning: A sociocultural perspective on pupil engagement, collaboration and agency in the classroom. University of Cambridge (unpublished $\mathrm{PhD}$ dissertation). 
Holstein, J. A., \& Gubrium, J. F. (1995). The active interview (Vol. vii). Thousand Oaks, CA, US: Sage Publications, Inc.

James, M., \& McCormick, R. (2009). Teachers learning how to learn. Teaching and Teacher Education, 25, 973-982.

LeCompte, M. D., Preissle, J., \& Tesch, R. (1993). Ethnography and qualitative design in educational research (2nd ed.). San Diego: Academic Press.

Marsh, B., \& Mitchell, N. (2014). The role of video in teacher professional development. Teacher Development: An International Journal of Teachers' Professional Development, 18(3), 403-417. http://doi.org/10.1080/13664530.2014.938106

Mason, J. (2002). Qualitative researching (2nd ed.). London: Sage.

Ministry of Education, Science, Vocational Training and Early Education (MOESVTEE, Zambia). (2014). Zambia: Education for All 2015 national review (p. 44). Zambia: S.1., Ministry of Education, Science, Vocational Training and Early Education, 2014. Retrieved from http://unesdoc.unesco.org/images/0023/002315/231573e.pdf

Mitra, S., Posarac, A., \& Vick, B. (2011). Disability and poverty in developing countries : a snapshot from the world health survey. Table 4.3, World Bank Social Protection and Labor Unit, 2011. The World Bank. Retrieved from http://documents.worldbank.org/curated/en/2011/04/14382786/disability-povertydeveloping-countries-snapshot-world-health-survey

Moon, B. (2007). Research analysis: Attracting, developing and retaining effective teachers: A global overview of current policies and practices. Paris: UNESCO.

Moon, B., and Dladla, N. (2013). Teachers and the development agenda: An introduction. In B. Moon (Ed.), Teacher Education and the Challenge of Development: a global analysis. (pp. 5-18). New York: Routledge.

Morrow, L. J. (1998). Whither algorithms? Mathematics educators express their views. In L. J. Morrow \& M. J. Kenney (Eds.), The teaching and learning of algorithms in school mathematics - 1998 Yearbook (pp. 1-6). Reston, VA: National Council of Teachers of Mathematics.

Moyo, N., \& Modiba, M. (2014). Theory and practice in in-service teacher learning: teachers' reconceptualisation of curriculum in history lessons. Research Papers in Education, 29(4), 438-456. http://doi.org/10.1080/02671522.2013.772222

Mubanga, R. (2012). School Program of In-service Training for the Term (SPRINT) Programme in Zambia -A Case of Collaboration Towards Self-Reliant Education Development. In Collaboration toward Greater Autonomy in Educational Development. Tokyo, Japan. Retrieved from http://home.hiroshima-u.ac.jp/cice/wp-content/uploads/Forum/JEF9/RuthMubanga-e.pdf 
National Research Council (Ed.). (2001). The Power of Video Technology in International Comparative Research in Education. Washington, DC: National Academy Press.

Ngware, M. W., Oketch, M., \& Mutisya, M. (2014). Does teaching style explain differences in learner achievement in low and high performing schools in Kenya? International Journal of Educational Development, 36, 3-12. Retrieved from http://www.sciencedirect.com/science/article/pii/S073805931400008X

Nsibande, R. N., \& Modiba, M. M. (2012). "I just do as expected". Teachers' implementation of Continuous Assessment and challenges to curriculum literacy. Research Papers in Education, 27(5), 629-645. http://doi.org/10.1080/02671522.2011.560961

Organisation for Economic Co-operation and Development [OECD]. (1998). Staying ahead: Inservice training and teacher professional development. Paris: Organisation for Economic Co-operation and Development.

O'Sullivan, M. C. (2002). Action research and the transfer of reflective approaches to in-service education and training (INSET) for unqualified and underqualified primary teachers in Namibia. Teaching and Teacher Education, 18, 523-539. http://doi.org/10.1016/S0742051X(02)00014-8

Power, T. (2013). The "New" New Technology: Exploiting the Potential of Mobile Communications and Open Educational Resources. In B. Moon (Ed.), Teacher Education and the Challenge of of Development: a Global Analysis (pp. 212-226). New York: Routledge.

Pryor, J., \& Westbrook, J. (2013). Preparing Teachers for Early Learning in Sub Saharan Africa In Centre for Commonwealth Education (CCE) 2013 Seminar Series. Cambridge: University of Cambridge, 2013. http://sms.cam.ac.uk/media/1503299

Rainio, A. P., \& Hofmann, R. (2015). Transformations in teachers' discourse about their students during a school-led pedagogic intervention. The European Journal of Social \& Behavioural Sciences XIII (2), pp. 1815-1829.

Randi, J., \& Corno, L. (2007). Theory into practice: A matter of transfer. Theory Into Practice, 46(4), 334-342. http://doi.org/10.1080/00405840701593923

Roth, W.-M., \& Lee, S. (2004). Science education as/for participation in the community. Science Education, 88(2), 263-291. http://doi.org/10.1002/sce.10113

Rubagiza, J., Were, E., \& Sutherland, R. (2011). Introducing ICT into schools in Rwanda: Educational challenges and opportunities. International Journal of Educational Development, 31(1), 37-43. http://doi.org/10.1016/j.ijedudev.2010.06.004

Scherer, P., \& Steinbring, H. (2006). Noticing children's learning processes - teachers jointly reflect on their own classroom interaction for improving mathematics teaching. Journal of Mathematics Teacher Education, 9(2), 157-185. 
Schweisfurth, M. (2015). Learner-centred pedagogy: Towards a post-2015 agenda for teaching and learning. International Journal of Educational Development, 40, 259-266.

http://doi.org/10.1016/j.ijedudev.2014.10.011

Schwille, J., \& Dembélé, M. (2007). Global perspectives on teacher learning: improving policy and practice. Paris: International Institute for Educational Planning.

Sherin, M. (2007). New perspectives on the role of video in teacher education. In J. Brophy (Ed.), Advances in Research on Teaching (Vol. 10, pp. 1-27). Bingley, UK: Emerald.

Silverman, D. (2015). Interpreting qualitative data (5th ed.). Sage. Available from: https://books.google.co.uk/books?id=Tp94BgAAQBAJ

Smith, M. L., Elder, L., \& Emdon, H. (2011). Open Development: A new theory for ICT4D. Information Technologies \& International Development, 7(1), iii-ix. Retrieved from http://www.itidjournal.org/index.php/itid/article/download/692/290

Stein, M. K., Smith, M. S., \& Silver, E. (1999). The Development of Professional Developers: Learning to Assist Teachers in New Settings in New Ways. Harvard Educational Review, 69(3), 237-270. Retrieved from http://hepg.metapress.com/content/H2267130727V6878

Suurtamm, C., \& Vézina, N. (2010). Transforming pedagogical practice in mathematics: Moving from telling to listening. International Journal for Mathematics Teaching and Learning, 31. Retrieved from http://www.cimt.plymouth.ac.uk/journal/default.htm

Tikly, L. (2011). Towards a framework for researching the quality of education in low-income countries. Comparative Education, 47(1), 1-23. http://doi.org/10.1080/03050068.2011.541671

Tikly, L., \& Barrett, A. M. (2011). Social justice, capabilities and the quality of education in low income countries. International Journal of Educational Development, 31(1), 3-14. http://doi.org/10.1016/j.ijedudev.2010.06.001

Twining, P., Raffaghelli, J., Albion, P., \& Knezek, D. (2013). Moving education into the digital age: the contribution of teachers' professional development. Journal of Computer Assisted Learning, 29(5), 426-437.

Ulewicz, M. \& Beatty, A. Eds. and National Research Council. The Power of Video Technology in International Comparative Research in Education. Washington, DC: The National Academies Press, 2001.

UNESCO. (2010). Reaching the marginalized. Retrieved from http://www.unesco.org/new/en/education/themes/leading-the-internationalagenda/efareport/reports/2010-marginalization/

UNESCO. (2014). Teaching and learning: achieving quality for all. (P. Rose, Ed.). UNESCO Publishing. Retrieved from http://www.unesco.org/new/en/education/themes/leading-theinternational-agenda/efareport/reports/2013/

Hennessy et al. (2015). Pedagogic change ... - 32 
UNICEF. (2015). UNICEF Zambia - Education - Education. Retrieved May 1, 2015, from http://www.unicef.org/zambia/education.html

Uworwabayeho, A. (2011). Perspectives of ICT in Enhancing Learner centred Pedagogy in Rwandan Schools. Presented at the Computer Assisted Learning (CAL) conference, Manchester, UK.

Van Es, E. A., \& Sherin, M. G. (2008). Mathematics teachers" "learning to notice" in the context of a video club. Teaching and Teacher Education, 24(2), $244-276$.

http://doi.org/http://dx.doi.org/10.1016/j.tate.2006.11.005

Wallace, J. (2003). Introduction: Learning about teacher learning: reflections of a science educator. In J. Wallace \& J. Loughran (Eds.), Leadership and Professional Development in Science Education: New Possibilities for Enhancing Teacher Learning (pp. 1-16). London: Routledge Falmer.

Watson, C. (2014). Effective professional learning communities? The possibilities for teachers as agents of change in schools. British Educational Research Journal, 40(1), 18-29. http://doi.org/10.1002/berj.3025

Wells, J. G. (2007). Key design factors in durable instructional technology professional development. Journal of Technology and Teacher Education, 15, 101-118.

Westbrook, J., Durrani, N., Brown, R., Orr, D., Pryor, J., Boddy, J., \& Salvi, F. (2013). Pedagogy, curriculum, teaching practices and teacher education in developing countries: final report. (No. EPPI-Centre reference number 2110). Retrieved from https://eppi.ioe.ac.uk/cms/Default.aspx?tabid=3433

Wolfenden, F., Umar, A., Aguti, J., \& Abdel Gafar, A. (2010). Using OERs to improve teacher quality: emerging findings from TESSA. Presented at the Sixth Pan Commonwealth Forum on Open Learning, Kochi, India. Retrieved from http://wikieducator.org/PCF6/Formal_Education 